\title{
Management of shoot fly and stem borer on pearl millet crop
}

\author{
G.M. PARMAR*, R.P. JUNEJA AND K.D. MUNGRA
}

Main Millet Research Station, Department of Entomology, Junagadh Agricultural University, JAMNAGAR (GUJARAT) INDIA

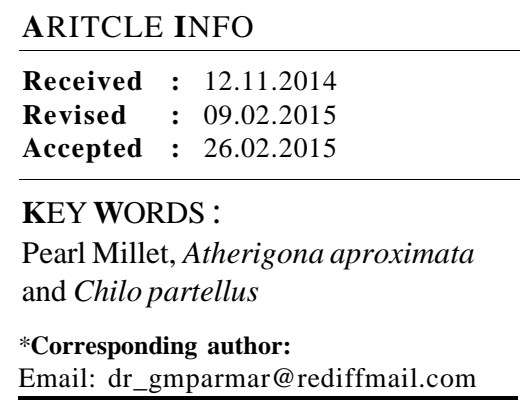

\begin{abstract}
A field experiment was conducted for management of shoot fly, Atherigona aproximata, Malloch and stem borer, Chilo partellus Swinhoe in pearl millet crop between 2006-07 to 2010-11 at Millet Research Station, Junagadh Agricultural University, Jamnagar. The results indicated that farmers of North Saurashtra Agro-climatic zone growing bajra crop are advised to apply two sprays of profenophos 0.05 per cent or fenobucarb 0.1 per cent at 20 and 40 days after germination for the control of shoot fly and stem borer infesting bajra crop.
\end{abstract}

How to view point the article : Parmar, G.M., Juneja, R.P. and Mungra, K.D. (2015). Management of shoot fly and stem borer on pearl millet crop. Internat. J. Plant Protec., 8(1) : 104-107. 